\title{
CHEMOSPHERE
}

\section{Short-term responses of Oryzias latipes (Pisces: Adrianichthyidae) and Macrobrachium nipponense (Crustacea: Palaemonidae) to municipal and pharmaceutical waste water in Beijing, China: survival, behaviour, biochemical biomarkers}

\author{
A. Gerhardt ${ }^{\text {a,b,*, L. Janssens de Bisthoven }}{ }^{\mathrm{a}, \mathrm{b}}, \mathrm{Z}$. Mo ${ }^{\mathrm{a}}$, C. Wang ${ }^{\mathrm{a}}$, \\ M. Yang ${ }^{\mathrm{a}}$, Z. Wang ${ }^{\mathrm{a}}$ \\ a State Key Laboratory of Environmental Aquatic Chemistry, Research Center for Eco-Environmental Sciences, P.O. Box 2871, \\ Beijing 100085, China \\ ${ }^{\mathrm{b}}$ LimCo International, An der Aa 5, D-49477 Ibbenbüren, Germany
}

Received 28 March 2001; accepted 10 October 2001

\begin{abstract}
Whole effluent toxicity was assessed for the fish Oryzias latipes and the prawn Macrobrachium nipponense for $18 \mathrm{~h}$ in a dilution series $(0-66 \%)$ of the inflow and effluent of a municipal waste water treatment plant as well as waste water from a teramycin producing pharmaceutical industry, before, during and after a pilot laboratory purification process. The waste waters caused acute toxicity as measured by inhibition of light emission in the luminiscent bacterium Vibrio qingaiensis sp. nov. (Q67). EROD and aryl hydrocarbon hydroxylase activity in in vitro carp liver-cells showed a dosedependent toxic response to the municipal waste water. Behavioural responses and time-to-death of fish and prawn, recorded online with the "Multispecies Freshwater Biomonitor" proved to be concentration- and time-dependent sensitive toxicity indicators in both types of waste water. Behaviour changed stepwise from normal activity to (increased or decreased) activity to more time spent on ventilation and finally to increased morbidity at higher concentration and time of exposure. The municipal waste water treatment plant managed to reduce toxicity to bacteria (Q67), prawn and fish. The pharmaceutical waste water treatment process still has to be improved, in order to reduce toxicity for fish and prawn. (c) 2002 Elsevier Science Ltd. All rights reserved.
\end{abstract}

Keywords: Toxicity; Waste water; Behaviour; Multispecies Freshwater Biomonitor

\footnotetext{
${ }^{*}$ Corresponding author. Address: LimCo International, An der Aa 5, D-49477 Ibbenbüren, Germany. Tel.: +49-5451970390.

E-mail addresses: limco.int@t-online.de (A. Gerhardt), wangzj@mail.rcees.ac.cn (Z. Wang).
}

\section{Introduction}

In 1995, industries in China discharged 27 billion $\mathrm{m}^{3}$ of waste water in open water bodies, municipal sources discharged 15 billion $\mathrm{m}^{3}$. Waste water accounted for about $4 \%$ of the total surface water runoff. Environmental policies to speed up investment in water supply and waste water treatment are a top priority. Safe drinking water extraction is a serious problem along the major rivers in Northern China. Treated waste water 
can replace the use of the limited drinking water in industries and irrigation-dependent agriculture (World Bank, 1998).

Conventional endpoints in acute toxicity tests have primarily assessed lethality. However, an organism's ability to function normally in an ecosystem may be impaired at sublethal toxicant concentrations. Behavioural endpoints however represent early, sensitive and highly integrative responses to toxicants and can be used as non-destructive measures for repeated or even continuous toxicological monitoring (Gerhardt, 1995). Non-invasive techniques have the following advantages over destructive methods: (1) in situ use, (2) population decrements are avoided, (3) legislative restrictions on the sacrifice of higher vertebrates can be overcome, (4) ecologically important species having reduced numbers and endangered species can be analysed and (5) repeated measures and time-series analysis are possible (Fossi, 1994).

To study effects of toxicants on the metabolism of animals, many biomarkers have been considered. However ecological relevancy of the results is often small because comparisons with toxicity endpoints on other biological organization levels are missing (Johnsson et al., 1993; Holdway et al., 1995). Cytochromes P450 are central catalysts in biotransformation of diverse xenobiotics and endogenous compounds. They can be induced by various xenobiotics (inductive xenobiotic metabolism), e.g. PAHs, PCBs, PCDs and PCDFs. They have frequently been used as rapid enzymatic fish bioassays. Another frequently applied rapid toxicity bioassay is the Microtox-test, based on bioluminescence as a reaction of inhibited energy metabolism of bacteria.

The aims of this study were to test dilutions of waste water from a municipal purification plant and a pharmaceutical industry by use of two standard toxicity methods, the P-450 biomarker for fish and the Microtox for bacteria, combined with a non-destructive new method based on behavioural stress responses measured online in the Multispecies Freshwater Biomonitor (MFB). Toxic orders (suborganismal, organismal, taxonomic hierarchy) as well as species-dependent sensitivity to two common types of waste water were investigated.

\section{Materials and methods}

\subsection{Test species}

Three test species of different taxonomic level representing a fish, a crustacean and a bacterium were used. The Japanese medaka (Oryzias latipes) is an oviparous freshwater killifish and has been widely used as toxicity bioassay organism, especially the early life stage test (Shima and Shimada, 1994; Rao et al., 1997; Chen and Cooper, 1999). Standard toxicity tests with fish (acute toxicity test, prolonged toxicity test following the OECD guidelines use amongst other species, also the medaka). The freshwater prawn (Macrobrachium nipponense) is widely spread in China, Japan and Taiwan and commercially exploited in Northern China for local consumption. Its description is found in Cai and Dai (1999). A new local species of luminescent bacterium, Vibrio qinghaiensis sp. nov. (strain Q67), isolated from the body surface of Cymnocypris przewalskii, one of the major edible fish product in Qinghai province, has been used for the Microtox test. This strain has been proposed to monitor heavy metals, organic compounds and toxicity of polluted river water samples (Ma et al., 2000).

\subsection{Test water}

\subsubsection{Miyun reservoir}

Reference water and the local test organism Macrobrachium nipponense were taken from Miyun reservoir (Mi-Res), a large drinking water reservoir $\approx 80 \mathrm{~km}$ north of Beijing. The Miyun reservoir is the largest reservoir in the water system of the Chao and Bai rivers. The maximum pondage is $43.75 \times 108 \mathrm{~m}^{3}$ with a corresponding water surface area of $188 \mathrm{~km}^{2}$. The average depth of water is $12.68 \mathrm{~m}$, maximum depth is $43.5 \mathrm{~m}$ (Chen, 1995). The reservoir is a major source for drinking water, flood prevention, irrigation, power generation and fish culturing. The reservoir is threatened by eutrophication (Chen, 1995). Analyses of the filtrate of water samples did not indicate any pollution with pesticides as measured with GC. According to the threshold values of the German drinking water law all measured parameters were well below the limits. The $\mathrm{pH}$ of the water varied between 7.4 and 8.4 .

\subsubsection{Municipal waste water treatment plant}

The mechanically (a sieve and a sedimentation tank) pretreated inflow (M-IF) and effluent (M-EF) from a waste water treatment plant in Beijing (capacity: 300,000 citizens) was studied. The treatment plant consisted of the following steps: mechanical, anaerobic biological, aerobic biological and sedimentation steps. The purification capability of the waste water treatment plant is characterised by the following parameters, monitored in the effluent (purification plant authorities, personal communication): COD: $19.4-60 \mathrm{mgl}^{-1}, \mathrm{BOD}_{5}$ : 20 $\mathrm{mgl}^{-1}, \mathrm{SS}: 30 \mathrm{mgl}^{-1}$, Total-P: up to $10 \mathrm{mg} \mathrm{l}^{-1}, N_{\text {tot }}$ : up to $40 \mathrm{mgl}^{-1}, \mathrm{~S}:<1 \mathrm{mgl}^{-1}$, DO: $<3 \mathrm{mgl}^{-1}$ and $\mathrm{pH}$ 7. According to German waste water guidelines, $\mathrm{P}$ is limited to $1-2 \mathrm{mgl}^{-1}, \mathrm{NH}_{3}-\mathrm{N}$ to $0.6 \mathrm{mgl}^{-1}, \mathrm{BOD}_{5}$ to $15 \mathrm{mg} \mathrm{l}^{-1}$ and COD to $75 \mathrm{mgl}^{-1}$. Concentrations of heavy metals including $\mathrm{Fe}$ did not diminish during the purification process, except $\mathrm{Mn}$, neither the anions and cations, except $\mathrm{P}$ (Tables 1 and 2). Analyses of the filtrate of water samples from the municipal waste water did not indicate any pollution with pesticides as measured with GC 
Table 1

Metal concentrations in the test water $\left(\mu \mathrm{gl}^{-1}\right)$

\begin{tabular}{lclrrrrrrrr}
\hline Samples & \multicolumn{1}{c}{$\mathrm{As}$} & $\mathrm{Cd}$ & \multicolumn{1}{c}{$\mathrm{Co}$} & \multicolumn{1}{c}{$\mathrm{Cr}$} & \multicolumn{1}{c}{$\mathrm{Cu}$} & \multicolumn{1}{c}{$\mathrm{Fe}$} & \multicolumn{1}{c}{$\mathrm{Mn}$} & $\mathrm{Mo}$ & $\mathrm{Ni}$ \\
\hline Mi-Res & 1.50 & 0.03 & 0.08 & 5.50 & 12.10 & 22.00 & 0.90 & 2.55 & 2.30 & 34.00 \\
DW & 10.0 & 1.0 & \multicolumn{1}{c}{-} & 50.00 & 300.00 & 200.00 & 50.00 & - & 50.00 & 3000.00 \\
M-IF & 2.84 & 0.00 & 0.37 & 4.00 & 2.29 & 21.00 & 32.20 & 2.68 & 1.20 & 36.00 \\
M-EF & 2.20 & 0.03 & 0.23 & 8.10 & 7.21 & 20.00 & 9.00 & 3.49 & 1.10 & 50.00 \\
P-IF* & 0.78 & 0.02 & 13.95 & 9.90 & 1.49 & 189.00 & 74.60 & 1.80 & 7.00 & 113.00 \\
P-IM & 0.68 & 0.01 & 8.14 & 11.20 & 2.10 & 90.00 & 73.60 & 0.43 & 8.00 & 83.00 \\
P-EF & 0.84 & 0.02 & 1.36 & 3.80 & 1.47 & 41.00 & 7.80 & 1.95 & 4.60 & 20.00 \\
\hline
\end{tabular}

$\mathrm{DW}$ - threshold values for drinking water, the metals $\mathrm{Hg}, \mathrm{Pb}$ and $\mathrm{Sn}$ were below $1 \mu \mathrm{g} 1^{-1}$. *P-IF: this waste water from the pharmaceutical industry was already diluted 15 times. Mi-Res.-Miyun reservoir (control water); M-IF-municipal purification plant inflow; M-EF-municipal purification plant outflow; P-IF- pharmaceutical waste water treatment inflow; P-IM-pharmaceutical waste treatment water pretreatment; $\mathrm{P}-\mathrm{EF}$ - pharmaceutical waste water treatment outflow.

Table 2

Water chemistry parameters $\left(\mathrm{mg}^{-1}\right)$

\begin{tabular}{lrrrrrrrrrr}
\hline Sample & \multicolumn{1}{c}{$\mathrm{Ca}$} & \multicolumn{1}{c}{$\mathrm{K}$} & $\mathrm{Mg}$ & \multicolumn{1}{c}{$\mathrm{Na}$} & \multicolumn{1}{c}{$\mathrm{Cl}$} & $\mathrm{P}$ & \multicolumn{1}{c}{$\mathrm{S}$} & $\mathrm{COD}$ & $\mathrm{NH}_{4}-\mathrm{N}$ & $\mathrm{NO}_{3}-\mathrm{N}$ \\
\hline Mi-Res & 36.41 & 5.87 & 9.02 & 10.90 & 0.36 & 0.22 & 12.33 & - & - & - \\
DW & 400.00 & 25.00 & 50.00 & 150.00 & 250.00 & 6.70 & & & 0.5 & - \\
M-IF & 47.97 & 12.37 & 12.76 & 45.90 & 1.83 & 5.62 & 15.77 & - & - & - \\
M-EF & 50.52 & 13.32 & 10.70 & 50.50 & 2.00 & 0.19 & 19.21 & 60 & $30-40+$ \\
P-IF* & 0.89 & 56.59 & 14.30 & 301.50 & 1.39 & 1.33 & 54.69 & 1000 & 125 & 0 \\
P-IM & 10.33 & 57.43 & 13.51 & 316.80 & 1.44 & 0.40 & 338.39 & 960 & 188 & 0 \\
P-EF & 29.43 & 121.02 & 10.17 & 81.70 & 0.63 & 0.03 & 25.66 & 260 & 38 & $2.7 \#$ \\
\hline
\end{tabular}

DW-thresholds for drinking water. + total-N; \#: P-EF contained up to $10.9 \mathrm{mg} \mathrm{l}^{-1} \mathrm{NO}_{2}-\mathrm{N}$. *P-IF: this waste water from the pharmaceutical industry was already diluted 15 times. Mi-Res.-Miyun reservoir (control water); M-IF-municipal purification plant inflow; M-EF-municipal purification plant outflow; P-IF-pharmaceutical waste water treatment inflow; P-IM-pharmaceutical waste treatment water pretreatment; $\mathrm{P}-\mathrm{EF}$ - pharmaceutical waste water treatment outflow.

(Södergren, personal communication). The $\mathrm{pH}$ values of the municipal waste water in- and effluents were 6.9-7.2.

\subsubsection{Pharmaceutical waste water}

The pharmaceutical waste water (P-IF) was already diluted 15 times and contained products of fermentation, metabolism and residues of teramycin as well as acid, alkali and organic dissolvents. This water was treated in a laboratory scale purification plant containing the following steps: anaerobic hydrolysis pretreatment column (sludge bed) (P-IM), followed by a series of a denitrification (sludge bed) and a nitrification column (fixed bed with plastic carrier), whose effluent was indicated in this study as P-EF. The $\mathrm{pH}$ of the water ranged from 6.5 to 8.0. This treatment plant achieved a 4-fold reduction in COD, a 2-fold reduction of teramycin, a 10 -fold reduction of ammonium-N. Na and $\mathrm{S}$ diminished in the effluent, whereas $\mathrm{Ca}$ and $\mathrm{K}$ increased. The metals $\mathrm{Co}, \mathrm{Cr}, \mathrm{Mn}, \mathrm{Zn}$ and $\mathrm{Fe}$ were decreased during the purification process (Tables 1 and 2).

\subsection{Test design}

The test organisms were either caught in the field (Macrobrachium nipponense from Miyun reservoir) or obtained from a culture at the Animal Institute of the Chinese Academy of Sciences (Oryzias latipes). The organisms were not fed during the experiments and meanwhile kept in aerated tapwater at room temperature $\left(15-18^{\circ} \mathrm{C}\right)$. Circumneutral $\mathrm{pH}$ and continuous light were maintained. Mean sizes of organisms were $2.3 \mathrm{~cm}$ (SD: $0.7 \mathrm{~cm}, N: 10$ ) for fish and $2.5 \mathrm{~cm}$ (SD: $0.5, N: 8$ ) for prawn for the tests in municipal waste water. Mean sizes of organisms were $2.6 \mathrm{~cm}$ (SD: $0.5 \mathrm{~cm}, N: 21)$ for fish and $4.6 \mathrm{~cm}$ for prawn (SD: $0.5, N: 25)$ for the tests with pharmaceutical waste water. Test organisms $(N=6-8)$ were exposed individually in test chambers of the MFB. The chambers were of $4 \mathrm{~cm}$ length and $2.5 \mathrm{~cm}$ diameter, for organisms smaller than $4 \mathrm{~cm}$ and of $10 \mathrm{~cm}$ length and $3.5 \mathrm{~cm}$ diameter for larger animals. Experiments were performed in 101 tanks containing 51 test water in a static test design. The test solutions were freshly prepared as a dilution series of the respective type of waste water with dechlorinated tapwater (provided by Miyun reservoir) in a log-linear series as follows: $6(1: 17), 12$ $(1: 8), 30(1: 3), 50(1: 2)$ and $66(1: 1.5) \%$ toxic water. The organisms were acclimated to the test chambers in dechlorinated tapwater for hours before exposure to the toxic pollution pulse. Mixing of the water was supported by stirring for $5 \mathrm{~min}$. Behavioural changes were recorded 
online during 18-20 h (record. $4 \mathrm{~min}$, interval: $6 \mathrm{~min}$ ). Water chemistry parameters $(\mathrm{pH}$, temperature, DO) were recorded regularly during the experiments. DO varied normally between $70 \%$ and $100 \%$.

\subsection{Chemical analyses}

$\mathrm{NH}_{4}^{+}-\mathrm{N}$ was determined according to Water and Wastewater Monitoring and Analyzing Method (1989). COD was determined on a rapid COD analysing meter (CTL-12, Huatong, Chengde, Hebei). TOC was measured on a TOC analyzer (Shimadzu, TOC-500, Japan). $\mathrm{SO}_{4}^{2-}, \mathrm{NO}_{3}^{-}-\mathrm{N}, \mathrm{NO}_{2}^{-}-\mathrm{N}$ and oxalic acid were determined by ion chromatography (IC100, YEW, Japan) and organic acid on the same equipment with a different column. Teramycin was measured by ion chromatography (Dx 4000i, Dionex, USA) with a Dionex PCX-100 analytical column. The metals, $\mathrm{Cl}, \mathrm{P}$ and $\mathrm{S}$ were determined by ICP-AES and ICP-MS.

\subsection{Toxicity parameters and methods}

\subsubsection{Behaviour and survival}

Behaviour patterns (locomotion, ventilation) and time-to-death (TTD) were recorded online with the MFB based on quadropole impedance conversion technique (Gerhardt et al., 1994; Gerhardt, 1999, 2000). Quadropole impedance conversion technique is based on the animal functioning as resistant in an alternating current between electrodes at the opposite walls of a water-filled test chamber. A second, non-current carrying pair of electrodes records the changes in impedance caused by the animals movements and generates specific electrical signals for different kinds of behaviour, such as locomotion and ventilation (Gerhardt et al., 1994). Signal analysis is based on a stepwise discrete fast Fourier transform thus generating a histogram of the frequency of occurrence of signal-frequencies between 0.5 and 8.5 $\mathrm{Hz}$ (in steps of $0.5 \mathrm{~Hz}$ ) (Gerhardt et al., 1998).

\subsubsection{Bioluminescence toxicity bioassay (Q67)}

A modified Microtox-test (Ma et al., 2000) was used, in order to avoid the use of the marine $P$. phosphoreum for toxicity tests in freshwater. The assays were carried out by adding $0.1 \mathrm{ml}$ bacterial suspension and $0.9 \mathrm{ml}$ test medium to a commercially available low-background plastic tube. The initial and the final (after $20 \mathrm{~min}$ exposure) relative light units (RLU) were recorded by a luminator (Berthold, Germany) at $22{ }^{\circ} \mathrm{C}$.

\subsubsection{Cytochrome P-450 mono-oxygenase activity}

Cytochrome P-450 dependent MFOs belong to the detoxification enzymes, e.g. in fish liver-cells microsome fraction. These enzymes are of toxicological relevance due to their inducibility by numerous organic xenobiotics, e.g. PAHs, PCBs, furanes, dioxins and various pesticides. For this reason, the measurement of the catalytic activity of this enzyme system has been used as biomarker of exposure since the 1970s (Schramm et al., 1999). MFO-determination uses as substrate for P-450 ethoxyresorufin (EROD), which after reaction with $\mathrm{P}$ 450 and NADPH transforms to a fluorescent colour resorufin. EROD determination was performed by standard methods for preparation and protein determination using an UV-120-02 spectrophotometer (Bradford, 1976). The catalytic activity of the MFO-system was also measured by aryl hydrocarbon hydroxylase (AHH) reaction in a spectrophotofluorometer using 3-hydroxybenzo(a)pyrene as reference. Each assay was performed in triplicate and exposure of fish liver tissue at $25^{\circ} \mathrm{C}$ to toxic water lasted for $15 \mathrm{~min}$.

\subsection{Data analysis}

$\mathrm{LC}_{50}(6,12,18 \mathrm{~h})$ and $\mathrm{LT}_{50}(6 \%, 12 \%, 30 \%, 50 \%$ and $66 \%$ were calculated on ranked mortality percentages with the logit method when 2 or more partial kills were present or with the formula of Spearman-Kärber, when only one partial kill was present. As the survival data were obtained with dilution series of toxic waters in loglinear series and mostly only one partial kill occurred, no additional statistical modelling seemed appropriate (Hoekstra, 1993). Time-to-death (TTD, h) was calculated, according to the definition of "time where irreversible-inactivity started" from the online behaviour data and compared to the traditional $\mathrm{LT}_{50}$ methods. Regressions were calculated between TTD, time-to response, duration of response and concentration of toxic water.

For each animal, selected behavioural signal frequencies $(2,3$, and $5 \mathrm{~Hz}$ ) were plotted over time and analysed for "time to response" and "duration of response". Non-linear curve fitting according to the least square method was performed as well as partial linear regressions for response slopes. Original behavioural data (selected indicative frequencies) were $\arcsin \sqrt{x}$ transformed and analysed by repeated measures ANOVA for concentration-dependent differences throughout the whole experiment.

As after exposure time of $7 \mathrm{~h}$, responses could be seen in most concentration levels, these data were treated with canonical variates analysis (CVA) (Podani, 2000) in order to show behavioural variances in the data set, indicate the most discriminating behavioural frequencies and their concentration-dependent shifts.

Toxic risks were calculated by $p T={ }^{10} \log (T / 100)$, where $T$ is number of times dilution/concentration needed to reach $\mathrm{EC}_{50}$ in luminescent bacteria test (Polman and De Zwart, 1993) for Q67 and the other biomarkers in order to compare toxicity orders. 


\section{Results}

\subsection{Survival and normal behaviour of fish and prawn in Miyun reservoir}

Killifish showed swimming activity with the tail (up to $2.5 \mathrm{~Hz}$ and $2.5 \mathrm{~V}$ ), movements of the dorsal and pectoral fins while not swimming $(2-2.5 \mathrm{~Hz}, 1.3 \mathrm{~V})$, mouth and operculum movements (ventilation) were between 3 and $4 \mathrm{~Hz}$ and below $1 \mathrm{~V}$ signal amplitude (Fig. 1). Fish exhibited a greater variance in control behaviour than prawn, the latter showing more consisting and homogenous behaviour. Prawn showed locomotory activity at high amplitudes (up to $2.5 \mathrm{~V}$ ) and low frequencies $(0.5-2.5 \mathrm{~Hz})$ and ventilation at low amplitudes (up to $500 \mathrm{mV}$ ) and high frequencies (3-5.5 Hz) (Fig. 2). No mortality occurred in Miyun water in either test species.

\subsection{Survival in municipal waste water}

The inflow (M-IF) was toxic at dilutions of $\geqslant 30 \%$ (prawn) and at $66 \%$ (fish) (Table 3). The $\mathrm{LC}_{50}$ for prawn was $44 \%$ after $6 \mathrm{~h}$ and $26 \%$ after $18 \mathrm{~h}$. TTD decreased in a significant linear $(p<0.05)$ concentration-dependent way for both species, the differences between the species being not significant (prawn: $y=11.12-0.14 x$; fish: $y=7.08-0.07 x$ ). The $\mathrm{LT}_{50}-\mathrm{M}-\mathrm{IF}$ for prawn was $7 \mathrm{~h}($ at $30 \%)$ and $3 \mathrm{~h}(\geqslant 50 \%) . \mathrm{LC}_{50}$ and $\mathrm{LT}_{50}$ values for fish could not be calculated due to lack of enough partial kills. The effluent from the municipal waste water treatment plant (M-EF) was not toxic within $18 \mathrm{~h}$ of exposure in any of the dilutions tested with fish and prawn.

\subsection{Survival in pharmaceutical waste water}

The pharmaceutical waste water (P-IF) from the antibiotic production line was toxic in a significant $(p<0.05)$ concentration-dependent way for both species, no significant differences between both test species were found. The $\mathrm{LT}_{50}$ and TTD for both species decreased in a significant $(p<0.05)$ linear concentrationdependent way for all types of pharmaceutical waste water (fish: $y=13.6-0.25 x$; prawn: $y=17.0-0.34 x$ ). The $\mathrm{LC}_{50}(18 \mathrm{~h})$ of P-IF for prawn and fish were $4 \%$ and $27 \%$, respectively (Table 3 ). After the first treatment step (P-IM), toxicity at low concentrations increased, the slopes of the regression line between concentration and TTD were less steep, and no significant differences between the species were found (fish: $y=9.6-0.14 x$; prawn: $y=10.8-0.14 x$ ). The whole purification process reduced toxicity for prawn by a factor of 6 (Table 3 ), while for fish toxicity remained substantial.

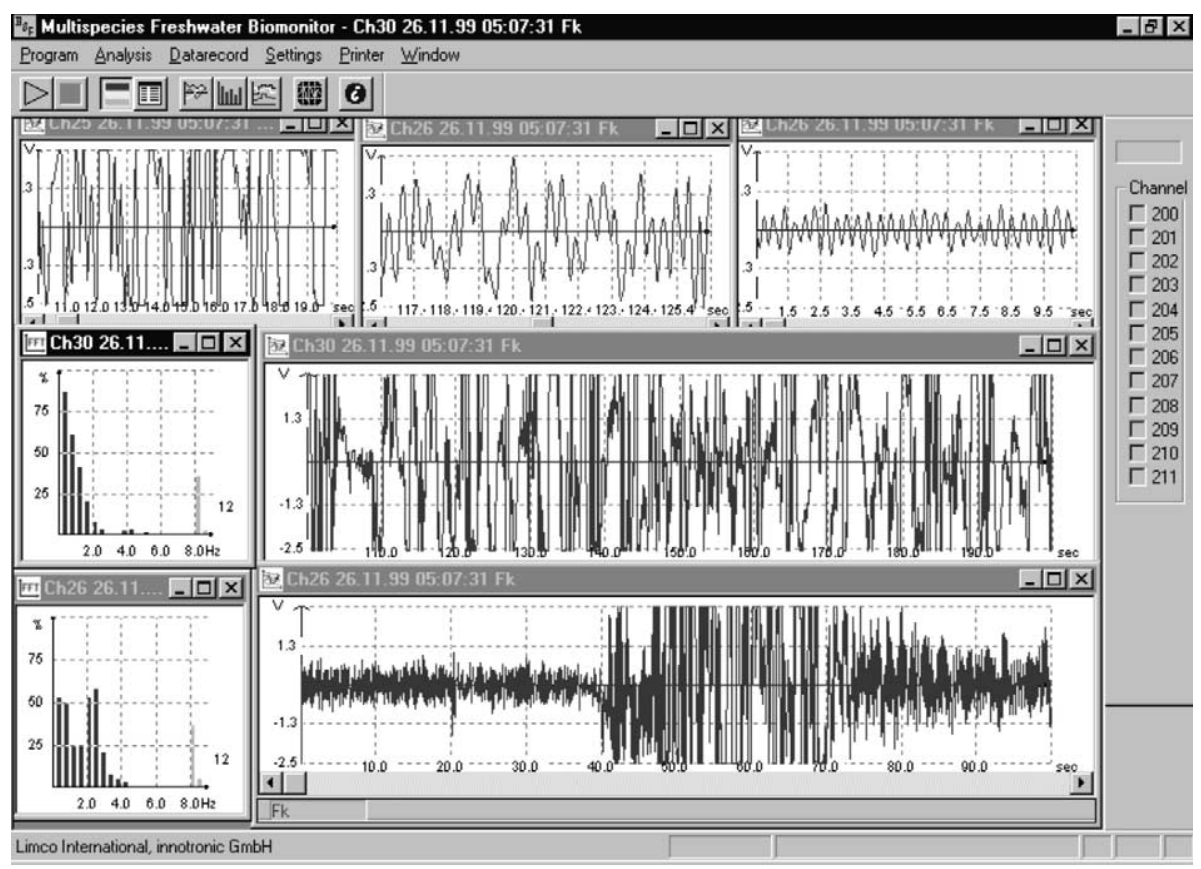

Fig. 1. Behavioural pattern of Oryzias latipes . Top left: swimming, top middle: movements with the fins, top right: ventilation (mouth and operculum). Middle: FFT and signal of a fish spending most time on locomotion. Bottom: FFT and signal of a fish spending $>50 \%$ of the time on fin movements and ventilation while not swimming. 


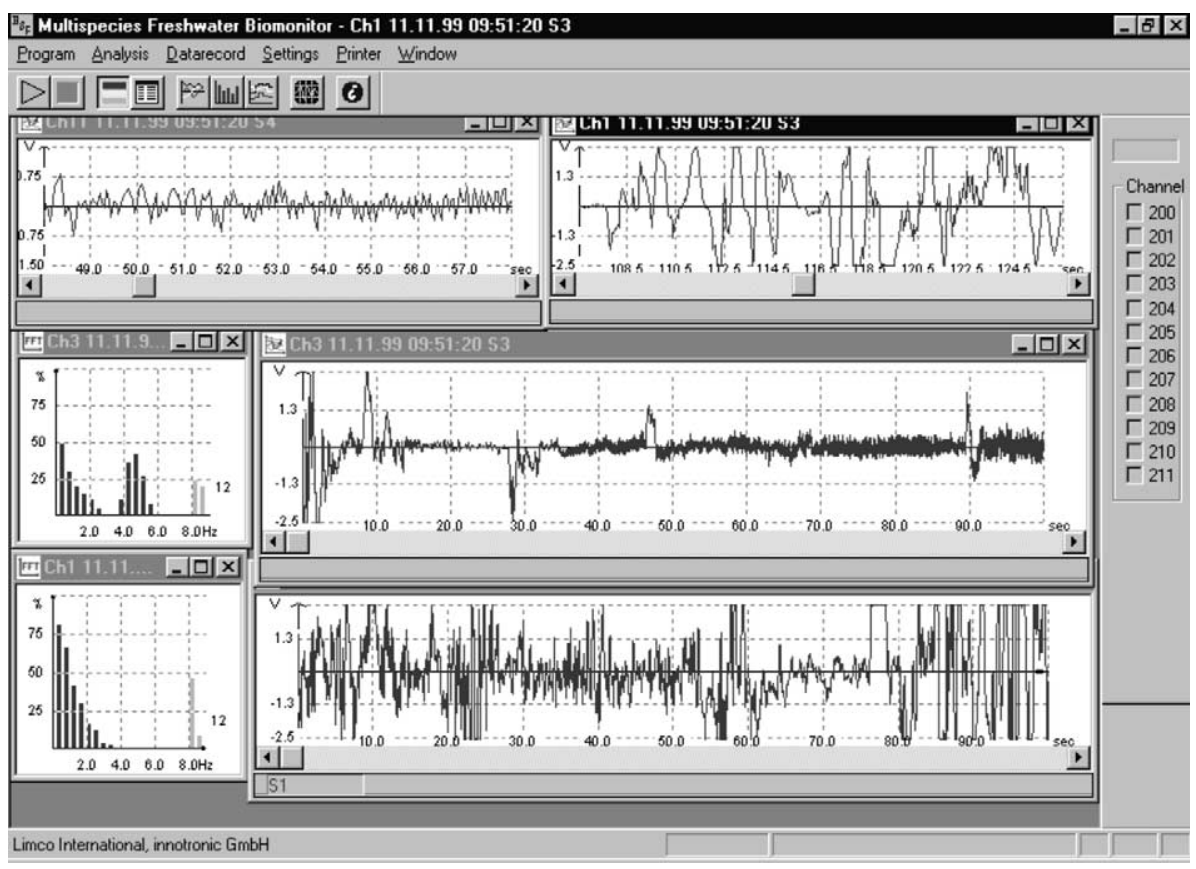

Fig. 2. Behavioural pattern of Macrobrachium nipponense in the test chambers in Miyun reservoir water, after 15 min acclimation time. Top left: ventilation signals $(\approx 5 \mathrm{~Hz})$, top right: locomotion signals $(0.5-2.5 \mathrm{~Hz})$, middle: $\mathrm{FFT}$ and signal of a prawn spending most time on ventilation, bottom: FFT and signal of a prawn spending most time on locomotion.

\subsection{Behavioural responses in municipal waste water}

\subsubsection{Stress-indicative frequencies and behavioural shifts}

As after $7 \mathrm{~h}$ of exposure fish showed visible responses in most of the treatments, a CVA was performed to show variance of the data and to reveal which behavioural frequencies were most indicative for the separation of the treatment groups (Fig. 3). For fish, locomotion ( $\mathrm{Bd} 1,0.5-2.5 \mathrm{~Hz}$ ) as well as $3 \mathrm{~Hz}$ (ventilation) revealed a clear concentration-dependent shift from increased locomotion $(2 \mathrm{~Hz})$ as first stress response to increased ventilation $(3 \mathrm{~Hz})$ in the higher concentrations of the effluent (locomotion and ventilation $p<0.05)$. In the inflow, a direct response towards increased ventilation was observed. A clear linear concentration- and time-dependency was found for stress responses at $3 \mathrm{~Hz}$ (time to response: $y=5.59-0.07 x$; duration of response: $y=10.6+0.05 x)$.

\subsubsection{Response times and slopes}

For fish, $2 \mathrm{~Hz}$ was chosen as most indicative frequency for time-dependent stress responses as here the shift between locomotion and ventilation occurs (Fig. 1). Time spent on $2 \mathrm{~Hz}$ of a mean of eight fish was plotted as least square fit over the whole experimental period (Fig. 4).

A concentration-dependent decrease in time to response (i.e. time where a significant ( $>10 \%$ deviation) and consistent shift in $2 \mathrm{~Hz}$ started) in municipal waste water inflow was found for fish (Fig. 4). Significant differences were found between different concentrations of municipal waste water and the control $(p<0.05)$. The effluent was less toxic, as indicated by reduced mortality, but showed increased locomotory stress responses in fish at concentrations of $\mathrm{M}-\mathrm{EF} \geqslant 30 \%$.

For prawn 3 and $5 \mathrm{~Hz}$, both characterizing ventilation, were chosen as stress indicators (Fig. 2). Although in the inflow TTD was concentration-dependent, no clear concentration-dependent shifts in responses could be found over time, however ANOVA revealed significant lower ventilation of prawn at intermediate concentrations of municipal waste water inflow $(p<$ $0.05)$.

\subsection{Behavioural responses in pharmaceutical waste water}

\subsubsection{Stress-indicative frequencies and behavioural shifts}

A typical shift in behaviours of prawn exposed to pharmaceutical waste water, especially after the first pretreatment, where also mortality increased, occurred as follows. After initial increase in time spent on ventilation $(3 \mathrm{~Hz})$, activity $(2 \mathrm{~Hz})$ and ventilation decreased towards morbidity and death $(p<0.05)$ (Fig. 3). With increasing concentration of pharmaceutical waste water inflow and pretreated water the response time for increasing ventilation $(3-4 \mathrm{~Hz})$ decreased and duration of 
Table 3

Toxicity bioassays and mortality of prawn $(\mathrm{S})$ and fish $(\mathrm{F})$ in the waste waters. Bioassays are Q67 luminiscence inhibition (\%), induction of EROD (\%) and AHH (\%) $M(\%)$ : mortality, TTD: mean TTD (h \pm SD), LC $_{50}(18 \mathrm{~h})(\%$ toxic water, for after 6 and $12 \mathrm{~h}$ see text), $\operatorname{LT}_{50}(\mathrm{~h})$

\begin{tabular}{|c|c|c|c|c|c|c|c|c|c|c|c|}
\hline \multicolumn{4}{|c|}{ Toxicity bioassays } & \multicolumn{8}{|c|}{ Mortality } \\
\hline \multirow[t]{2}{*}{ Water } & \multirow[t]{2}{*}{ Q67 } & \multirow[t]{2}{*}{ EROD } & \multirow[t]{2}{*}{$\mathrm{AHH}$} & \multicolumn{2}{|c|}{$M(\%)$} & \multicolumn{2}{|c|}{ TTD (h) } & \multicolumn{2}{|c|}{$\mathrm{LC}_{50}(18 \mathrm{~h})$} & \multicolumn{2}{|c|}{$\mathrm{LT}_{50}$} \\
\hline & & & & $\mathrm{S}$ & $\mathrm{F}$ & $\mathrm{S}$ & $\mathrm{F}$ & $\bar{S}$ & $\mathrm{~F}$ & $\mathrm{~S}$ & $\mathrm{~F}$ \\
\hline MI-RES & $20(0,3)$ & $126(3)$ & $100(0)$ & 0 & 0 & - & - & - & - & - & - \\
\hline$M-I F$ & & & & & & & & 26 & & & \\
\hline M-IF 6 & - & - & - & 0 & 0 & - & - & - & - & - & - \\
\hline M-IF 12 & - & - & - & 0 & 0 & - & - & - & - & - & - \\
\hline M-IF 30 & - & $1219(18)$ & - & 88 & 14 & $7(0,5)$ & 5 & - & - & 7 & - \\
\hline M-IF 50 & $-10(0,2)$ & $1299(50)$ & $192(6)$ & 100 & 0 & $4(2)$ & - & - & - & 3 & - \\
\hline M-IF 66 & - & $1453(51)$ & - & 100 & 100 & $2(0,5)$ & $2,5(1)$ & - & - & 3 & - \\
\hline M-IF100 & $-89(2,6)$ & $1787(46)$ & $313(7)$ & & & & & & & & \\
\hline \multicolumn{12}{|l|}{$M-E F$} \\
\hline M-EF 30 & - & - & - & 0 & 0 & - & - & - & - & - & - \\
\hline M-EF 50 & $11(0,1)$ & $456(4)$ & - & 0 & 0 & - & - & - & - & - & - \\
\hline M-EF 66 & - & - & - & 0 & 0 & - & - & - & - & - & \\
\hline M-EF 100 & $25(0,7)$ & $826(35)$ & $53(1)$ & & & & & & & & \\
\hline$P-I F$ & & & & & & & & 4 & 27 & & \\
\hline P-IF 6 & - & - & - & 88 & 0 & $13(4)$ & $13(3)$ & - & - & 11 & - \\
\hline P-IF 12 & - & - & - & 100 & 57 & $16(1)$ & $10(7)$ & - & - & 9 & 18 \\
\hline P-IF 30 & - & - & - & 100 & 75 & $5,5(3)$ & $5(3)$ & - & - & 7 & 7 \\
\hline P-IF 50 & - & - & - & 100 & 100 & $0,5\left(5^{\prime}\right)$ & $1,5\left(40^{\prime}\right)$ & - & - & 3 & 3 \\
\hline P-IF 100 & $-100(6)$ & $356(18)$ & 367 & & & & & & & & \\
\hline \multicolumn{12}{|l|}{$P-I M$} \\
\hline P-IM 6 & - & - & - & 100 & 100 & 11(3) & $8\left(20^{\prime}\right)$ & - & - & 12 & \\
\hline P-IM 12 & - & - & - & 100 & 100 & $9(2)$ & $9(0,5)$ & - & - & 9 & 13 \\
\hline P-IM 30 & - & - & - & 100 & 100 & $5\left(4^{\prime}\right)$ & $5\left(50^{\prime}\right)$ & - & - & 3 & 8 \\
\hline P-IM 50 & - & - & - & 100 & 83 & $5(5)$ & $9(6)$ & - & - & - & - \\
\hline$P-E F$ & & & & & & & & 25 & 33 & & \\
\hline P-EF 6 & - & - & - & 0 & 0 & - & - & - & - & - & - \\
\hline P-EF 12 & - & - & - & 0 & 50 & - & $16(1,5)$ & - & - & - & 16 \\
\hline P-EF 30 & - & - & - & 0 & 67 & - & 11(4) & - & - & - & 13 \\
\hline P-EF 50 & - & - & - & 100 & 88 & $4(1)$ & $11(4)$ & - & - & 3 & 13 \\
\hline P-EF100 & $265(1)$ & $313(4)$ & 305 & & & & & & & & \\
\hline
\end{tabular}

MI-RES: Miyun reservoir, M-IF: municipal waste inflow; M-EF: municipal waste effluent, P-IF: pharmaceutical waste inflow; P-IM: pharmaceutical waste pretreatment; P-EF: pharmaceutical waste effluent. Absence of values means not measured or not calculated.

response increased (prawn: P-IF: $10.48-0.29 x$; P-IM: $9.26 \exp (-0.053 x)$ and duration of response increased linearly (prawn: P-IF: $9.33+0.18 x$ ).

\subsubsection{Response times and slopes}

Decreased locomotion $(2 \mathrm{~Hz})$ of fish revealed a clear significant $(p<0.05)$ concentration-dependent shift towards shorter response times and indicated morbidity (Fig. 5).

The pharmaceutical waste water pretreatment (P-IM) provoked a serious increase in locomotion of fish at higher concentrations ("escape") during the first hours of exposure and activity decreases with morbidity towards the end of experiment, thus significant differences to the control and $\leqslant 12 \%$ concentration levels $(p=$ 0.001 ). The effluent of the pharmaceutical waste water was less toxic as indicated by longer response times and smoother response slopes. Significant differences of concentration levels $30 \%$ and $50 \%$ from the lower levels were found $(p=0.05)$.

For prawn, increased ventilation $(3-5 \mathrm{~Hz})$ was a significant $(p<0.05)$ concentration-dependent stress indicator in the pharmaceutical waste water (Fig. 6). The pretreated water caused directly more severe and faster behavioural responses than the inflow, whereas the effluent provoked behavioural responses only at P-EF $50 \%$ (ventilation of $5 \mathrm{~Hz}$ ). All treatments revealed significant differences from the control $(p<0.05)$. 
(a)

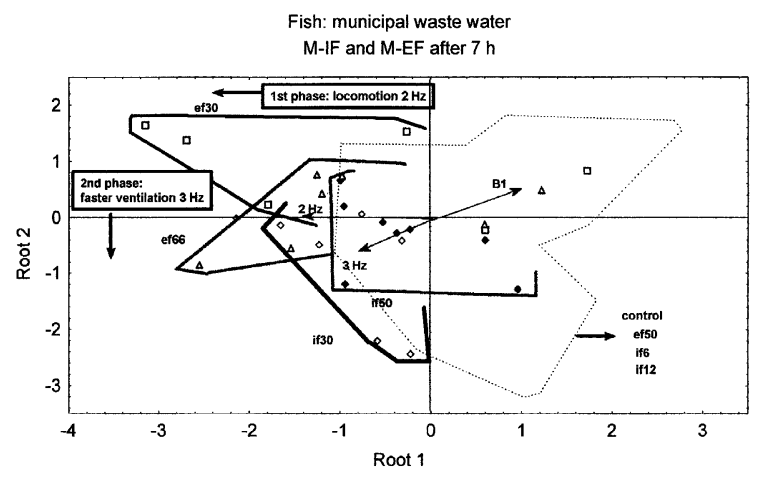

(b)

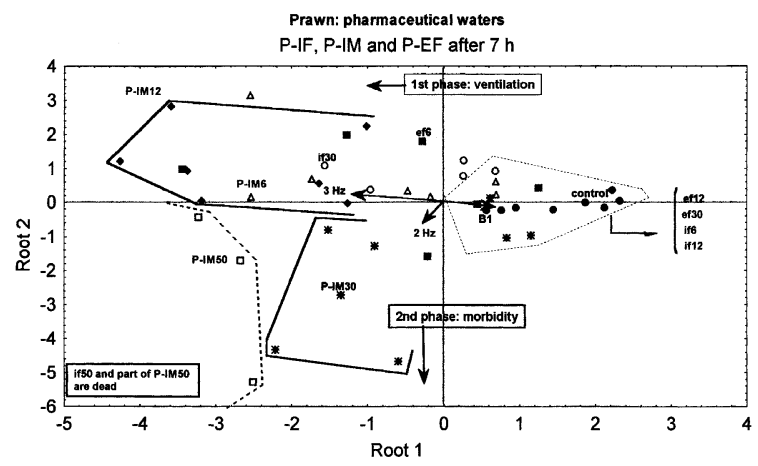

Fig. 3. Biplots of CVA for behavioural data on (A) fish in municipal waste water and (B) prawn in pharmaceutical waste water, after $7 \mathrm{~h}$ of exposure. M-IF-municipal waste water influent in purification plant, $\mathrm{M}-\mathrm{EF}$ - municipal waste water effluent after purification. Pharmaceutical waters: P-IF-influent before purification, P-IM-after pretreatment, P-EFeffluent after purification. Codes: e.g. ef 12 -effluent $12 \%$, P-IM30 - pretreatment 30\%, if6-inflow 6\%. Each individual dot represents one animal. Dots in control area left out for clarity. Arrows represent behavioural frequencies (ventilation at $3 \mathrm{~Hz}$ or locomotion at $\mathrm{B} 1$, summarizing $0.5-2 \mathrm{~Hz}$ and $2 \mathrm{~Hz}$ ) which significantly contributed to separation of group centroids $(p<0.05)$.

\subsection{Bacterial bioassay, EROD and aryl hydrocarbon hydroxylase}

The light emission of Q67 was inhibited by both types of inflowing waste waters, but showed similar low values for the unpolluted Miyun water and the effluent of the municipal purification plant. It reflected the dilution steps and showed an improvement of water quality from M-IF to M-EF and from P-IF to P-EF. EROD and AHH activity showed a concentration-response relationship with the dilution series of the municipal waters (Table 3) by improvement from M-IF to M-EF by a factor 2 (EROD) and 6 (AHH). EROD and AHH scored similarly for P-IF and P-EF, i.e. three times the control (a)

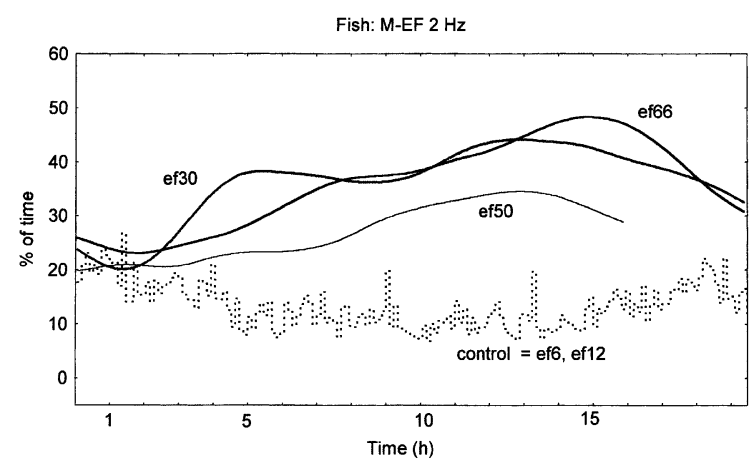

(b)

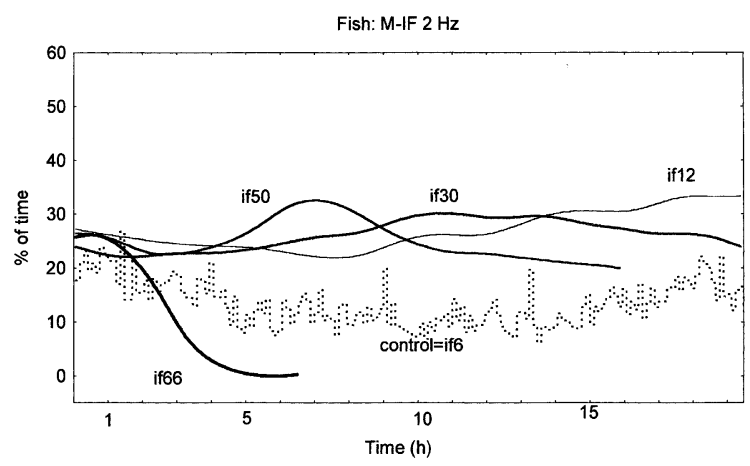

Fig. 4. Behavioural responses of fish at $2 \mathrm{~Hz}$ to municipal waste water before (M-IF) and after (M-EF) purification. Least squares fit of data (mean of eight animals), except for control where stepwise plot of data is given. Linear regressions $(p<0.05, r>0.76)$ for slope of increase of responses: ef30 $=$ $-7.3+1.3$ time; $\quad$ ef $50=6.9+0.3$ time $; \quad$ ef $66=14.1+0.3$ time; if $12=13.6+0.1$ time $; \quad$ if $30=16.2+0.2$ time $; \quad$ if $50=9.6+$ 0.4 time.

values of water from Miyun reservoir. The $\mathrm{EC}_{50}$ for Q67 of $40 \% \mathrm{M}-\mathrm{IF}$ was the basis for the comparison of toxic orders calculated as $p T$ values. According to this formula, the toxic risk of M-IF was "serious" for fish survival, "increased" for all other parameters and species. The $\mathrm{EC}_{50}$ for $\mathrm{EROD}$ was $10 \%$ and $\mathrm{EC}_{50}$ for prawn $(3 \mathrm{~Hz}$, ventilation) was $7 \%$, i.e. the behavioural stress response was the most sensitive test. For fish and other types of waste water this comparison was not possible due to high mortalities, lack of data or high variability of data.

\section{Discussion}

\subsection{Survival and bioassays}

\subsubsection{Municipal waste water}

In the municipal waste water treatment plant, all biotests including exposure of fish and prawn, Q67, 
(a)

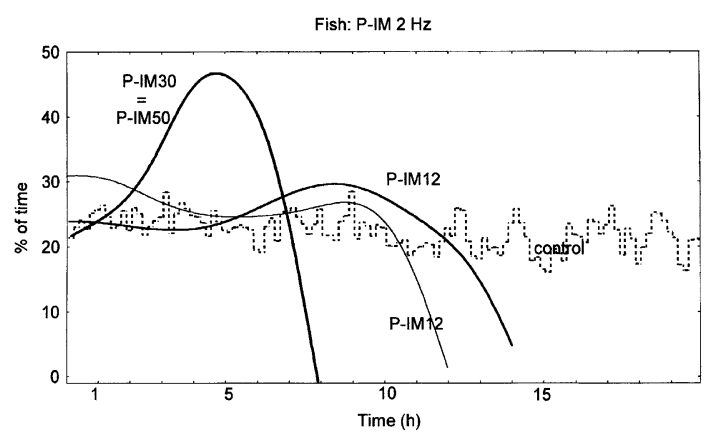

(b)

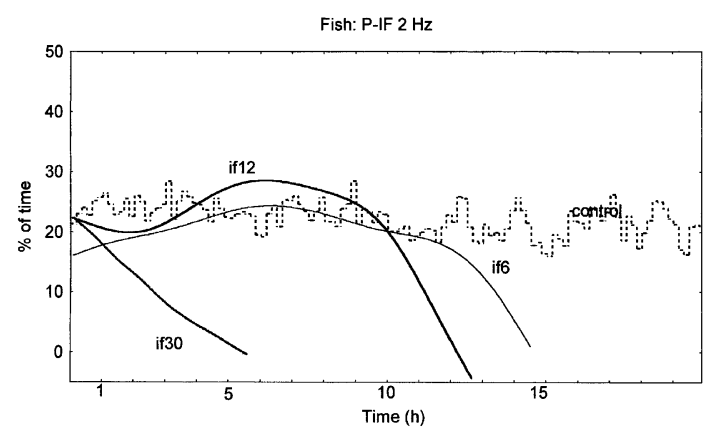

(c)

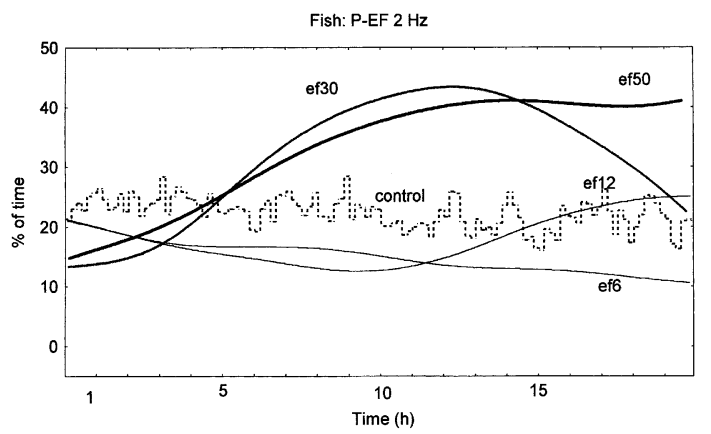

Fig. 5. Behavioural responses of fish at $2 \mathrm{H}_{3}$ and $5 \mathrm{~Hz}$ to pharmaceutical waste water in function of time of exposure. P-IF: before treatment, P-IM: after pretreatment, P-EF: after purification. Least squares fit of data (mean of eight animals), except for control where stepwise plot of data is given. Linear regressions $(p<0.05, r>0.86)$ for slope of increase of responses: ef $30=6.8+0.6$ time; ef50 $=13.7+0.2$ time.

EROD and AHH, showed reduced toxicity in the effluent, compared to the inflow. The MFO enzymes EROD and AHH are good indicators for organochlorine pesticides, PAHs and PCBs as well as paper mill effluents, being more sensitive than other biochemical, cellular and organ level biomarkers (Bucheli and Fent, 1995; Holdway et al., 1995). However, GC analysis of the water showed no elevated concentrations for organic compounds. Other unknown compounds must have caused EROD and AHH induction. Enzyme induction occurred during $15 \mathrm{~min}$ of exposure, being a fast biochemical response, in contrast to studies by Bankey et al. (1995) and Wolkers et al. (1996) reporting a slow induction in fish (Micropterus salmoides, Ictalurus punctatus) to bleached kraft mill effluent. EROD induction was much more expressed than AHH, which is supported by findings of Bankey et al. (1995) and Tuvikene et al. (1996).

Prawn showed 3-10x less sensitivity to the plant inflow than Gammarus pulex and G. tigrinus, exposed to a dilution series of mechanically pretreated raw water from a municipal purification plant: the $\mathrm{LC}_{50}(18 \mathrm{~h})$ was reached at a dilution factor of 1:4, whereas the dilution factors for G. pulex $\left(\mathrm{LC}_{50}(96 \mathrm{~h}): 1: 40\right)$ and G. tigrinus $\left(\mathrm{LC}_{50}(96 \mathrm{~h}): 1: 12.5\right)$ were much higher (Gerhardt and Quindt, 2000). In the undiluted raw water both Gammarus species died within $1 \mathrm{~h}$, comparable to the present results for the prawn. In both studies, the effluent of the municipal waste water treatment plant was not acutely toxic anymore to Crustacea.

\subsubsection{Pharmaceutical waste water}

The pilot treatment plant managed to reduce toxicity for bacteria (Q67), toxicity for invertebrates (prawn), but not for vertebrates (fish). EROD and AHH were low and could not differentiate between pharmaceutical waste water before and after treatment (P-IF and P-EF). The waste water treatment reduced $\mathrm{N}$-toxicity for prawn by creating slightly alkaline conditions, which resulted in a shift from $\mathrm{NH}_{3}$ to less toxic $\mathrm{NH}_{4}^{+}$(Burkhard and Jenson, 1993; Schubauer-Berigan et al., 1995). The effluent contained up to $10.9 \mathrm{mgl}^{-1}$ nitrite. Fish are known to be more sensitive to nitrite than crustaceans. e.g. $\mathrm{LC}_{50}$ for salmonids is $0.2-0.4 \mathrm{mg} \mathrm{NO} \mathrm{NO}_{2}-\mathrm{N}^{-1}$ (Shi 
(a)

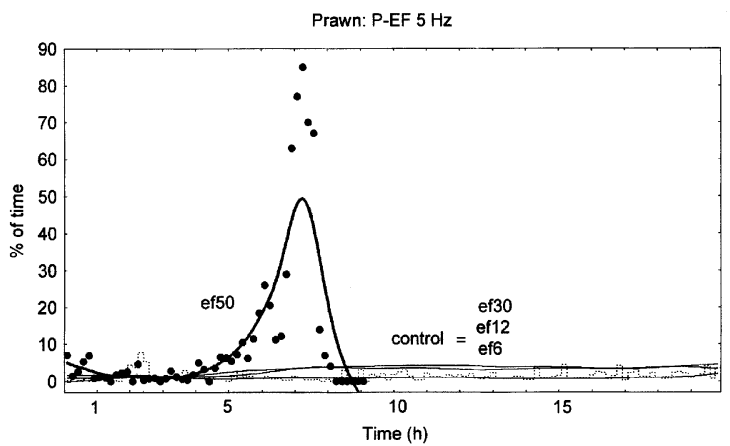

(c)

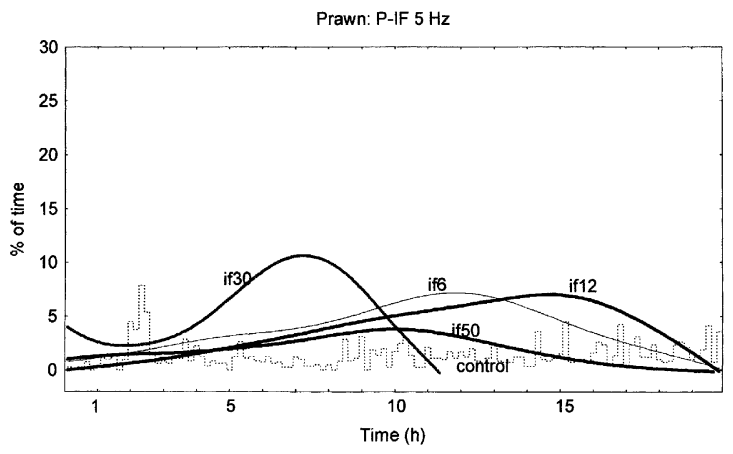

(b)

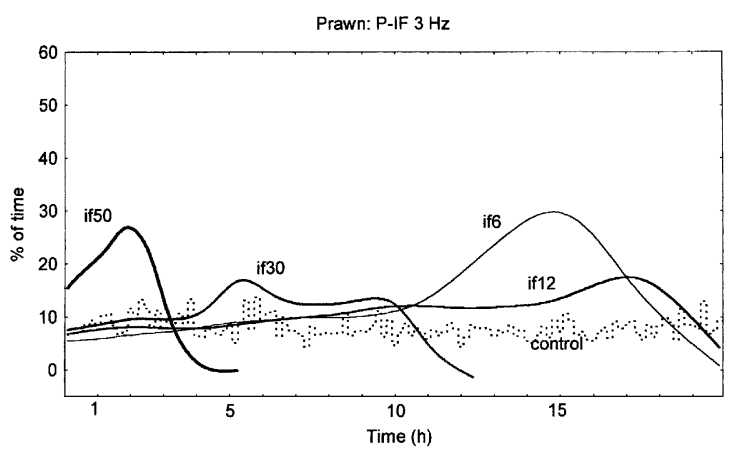

(d)

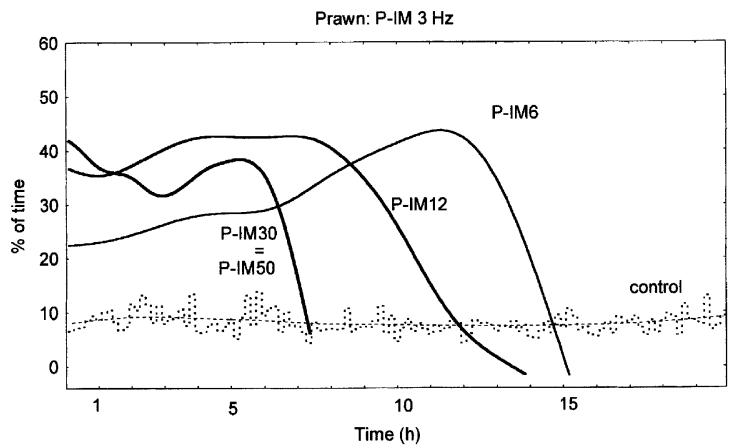

(e)

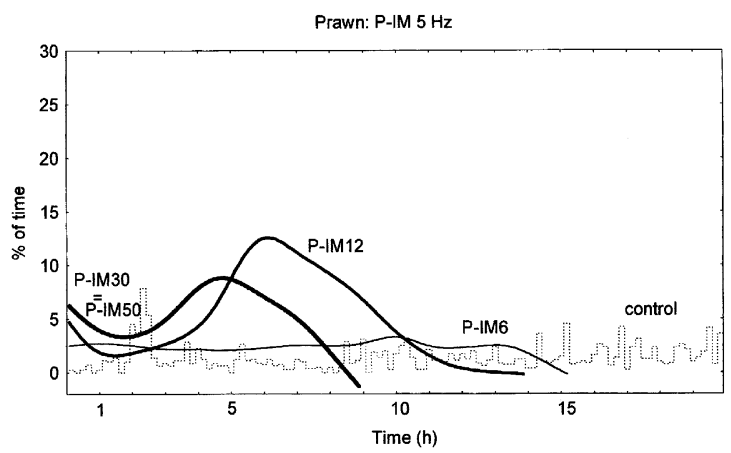

Fig. 6. Behavioural responses of prawn at 3 and $5 \mathrm{~Hz}$ to pharmaceutical waste water in function of time of exposure. P-IF: before treatment, P-IM: after pretreatment, P-EF: after purification. Least squares fit of data (mean of eight animals) except for control where stepwise plot of data is given.

and Mei, 1995), for Pimephales promelus after 96 h, 8.3 $\mathrm{mg}^{-1}$ (Burkhard and Jenson, 1993), while for crustaceans like M. nipponense, $\mathrm{LC}_{50}(48 \mathrm{~h}): 7.48 \mathrm{mg} \mathrm{NO} \mathrm{N}_{2}-\mathrm{N}$ $\mathrm{1}^{-1}$, the $\mathrm{LC}_{50}$ after $48 \mathrm{~h}$ of ammonia for Ceriodaphnia dubia at $\mathrm{pH} 8$ was $22.6 \mathrm{mgl}^{-1}$, the $\mathrm{LC}_{50}(48 \mathrm{~h})$ of ammonia for G. tigrinus at $\mathrm{pH} 7.7$ was $30 \mathrm{mgl}^{-1}$ (Gerhardt and Quindt, 2000).

\subsection{Behaviour of fish and prawn}

The evaluation of the behavioural responses measured online in the MFB revealed species-specific behaviours. Fish as pelagic organisms might have been stressed to a greater extent in the test chambers than benthic prawn, thus causing greater variance in behav- 
iour in the control. Both species showed concentrationdependent shifts in behaviour under exposure to waste water. Fish reacted with an initial escape followed by increased ventilation as described in the stepwise stress model, which describes a stepwise shift in different stress responses with increasing exposure time or concentration (Gerhardt, 1999, 2000). Prawn reacted first with increasing ventilation followed by decreasing ventilation and morbidity. At high concentrations the first stress response may be lost. The behavioural response observed in prawn exposed to municipal waste water occurred at higher concentrations of toxic waste water than those observed in an earlier study with G. tigrinus, which showed slightly increasing locomotion at dilutions of $1 \%$ and $2 \%$ toxic waste water over $96 \mathrm{~h}$ of exposure (Gerhardt and Quindt, 2000).

Comparing time to behavioural response with TTD revealed behavioural responses to be more sensitive than mortality as toxicity parameter. This is supported by findings for $O$. latipes by Rice et al. (1997). The increased locomotion of fish can be interpreted as escape reflex, which has been reported by Featherstone et al. (1993) for juvenile $O$. latipes exposed to phenol and strychnine and measured by non-invasive electrophysiological monitoring. Similarly, permethrin $(>0.009$ $\mathrm{mgl}^{-1}$ ), a neurotoxicant, induced hyperactivity in Oryzias latipes within $24 \mathrm{~h}$ of exposure, while at higher concentrations and $>24 \mathrm{~h}$ exposure, the fish became hypoactive. Furthermore, 2,4-dinitrophenol did not show behavioural responses before death while phenol, a polar narcotic, showed the fastest response (within $3 \mathrm{~h}$ at $30 \mathrm{mgl}^{-1}$ ), consisting of initial hyperactivity followed by hypoactivity (Rice et al., 1997). These examples illustrate the substance-specificity of behavioural responses in O. latipes.

\section{Conclusions}

The municipal waste water treatment plant managed to substantially reduce toxicity for bacteria (Q67), fish liver cells (EROD and AHH), prawn and fish (survival, behavioural stress). Enzyme induction, especially EROD gave results within $15 \mathrm{~min}$ of exposure, behavioural responses occurred within $0.5-9 \mathrm{~h}$ in a concentration- and time-dependent way and mortality occurred within 2-7 h. Biotest sensitivity for the municipal waste water (M-IF) concerning $\mathrm{EC}_{50}$ decreased as follows: prawn behaviour $>$ EROD $>$ Q67, prawn mortality $>$ fish mortality. As rapid toxicity screening, the bacterial bioassay Q67 is recommended for pharmaceutical waste water (antibiotic production), whereas EROD or AHH and behaviour were sensitive tests for municipal waste water toxicity. For continuous bio- monitoring the fast and sensitive ventilation responses in prawn were good indicators in the MFB. The MFB might be exposed in the effluent of the pharmaceutical treatment to continuously monitor the treatment success with prawn. With increasing optimization of the treatment process (further reduction of $\mathrm{N}$ and antibiotics), fish will be the more sensitive monitor species, which as vertebrates also indicate potential human toxicity.

\section{Acknowledgements}

Q67 was kindly provided by professor Wenjie Zhu, East China Normal University, Shanghai. Oryzias latipes were kindly provided by the Animal Institute of the Chinese Academy of Sciences, Beijing. Macrobrachium nipponense were obtained by local fishermen at Miyun reservoir, who are kindly acknowledged. The authors would also like to thank the personal of the local waste water treatment plant for co-operation. A grant from Academica Sinica (KZCX2-410) financed the stay of A. Gerhardt and L. Janssens de Bisthoven at SKLEAC, Beijing. We are indebted to A. Södergren (Lund University, Sweden) for performing GC analyses of water samples from Miyun and municipal waste water treatment plant. Moreover we thank T. Olsson (Lund University, Sweden) for performing ICP-AES and ICP-MS analyses of the water samples. Species determination of Macrobrachium nipponense was kindly performed by S. De Grave (Oxford University Museum of Natural History) and Y. Cai (National University of Singapore).

\section{References}

Bankey, L.A., van Veld, P.A., Borton, D.L., la Fleur, L., Stegemann, J.J., 1995. Responses to cytochrome P 4501A in freshwater fish exposed to bleached kraft mill effluents in experimental stream channels. Can. J. Fish. Aquat. Sci. 52, 439-447.

Bradford, M.M., 1976. A rapid and sensitive method for the quantification of microgram quantities of protein utilizing the principle of protein-dye binding. Anal. Biochem. 72, 248-254.

Bucheli, T.D., Fent, K., 1995. Induction of cytochrome P450 as a biomarker for environmental contamination in aquatic ecosystems. Critical Rev. Environ. Sci. Technol. 25 (3), 201-268.

Burkhard, L.P., Jenson, J.J., 1993. Identification of ammonia, chlorine, and diazinon as toxicants in a municipal effluent. Arch. Environ. Contam. Toxicol. 25, 506-515.

Cai, Y., Dai, A.Y., 1999. Freshwater shrimps (Crustacea: Decapoda: Caridea) from the Xishuangbanna region of Yunnan Province, southern China. Hydrobiologia 400, 211-241.

Chen, Y., 1995. A simulation model of eutrophication for the Miyun reservoir, Beijing. In: Munawar, M., et al. (Eds.), Aquatic Ecosystems of China: Environmental and 
Toxicological Assessment. SPB Academic Publishing, Amsterdam, Netherlands, p. 119.

Chen, C.M., Cooper, K.R., 1999. Developmental toxicity and EROD induction in the Japanese Medaka (Oryzias latipes) treated with dioxin congeners. Bull. Environ. Contam. Toxicol. 63, 423-429.

Featherstone, D., Drewes, C.D., Coats, J.R., Bradbury, S.P., 1993. A non-invasive neurotoxicity assay using larval medaka. Environmental Toxicology and Risk Assessment, Vol. 2, ASTM STP 1216, pp. 275-288.

Fossi, M.C., 1994. Non-destructive biomarkers in ecotoxicology. Environ. Health Perspectives 102 (Suppl. 12), 49-54.

Gerhardt, A., 1995. Monitoring behavioural responses to metals in Gammarus pulex (L.) (Crustacea) with impedance conversion. Environ. Sci. Pollut. Res. 2 (1), 15-23.

Gerhardt, A., 1999. Recent trends in online biomonitoring. In: Gerhardt, A. (Ed.), Biomonitoring of Polluted Water-Reviews on Actual Topics. TTP, Zürich, Switzerland, pp. 95-118.

Gerhardt, A., 2000. A new multispecies freshwater biomonitor for ecologically relevant supervision of surface waters. In: Butterworth, F.M., Gunatilaka, A., Gonsebatt, M. (Eds.), Biomonitors and Biomarkers as Indicators of Environmental Change. Plenum Press, New York, pp. 301-317.

Gerhardt, A., Carlsson, A., Ressemann, C., Stich, K.P., 1998. A new online biomonitoring system for Gammarus pulex (L.) (Crustacea): in situ test below a copper effluent in South Sweden. Environ. Sci. Technol. 32 (1), 150-156.

Gerhardt, A., Clostermann, M., Fridlund, B., Svensson, E., 1994. Monitoring of behavioral pattern of aquatic organisms with an impedance conversion technique. Environ. Int. 20 (2), 209-219.

Gerhardt, A., Quindt, K., 2000. Abwassertoxizität und -überwachung mit den Bachflohkrebsen Gammarus pulex (L.) und Gammarus tigrinus (Sexton) (Crustacea: Amphipoda). Wasser und Boden 52 (10), 19-26.

Hoekstra, J.A., 1993. Statistics in ecotoxicology. Quantifying the biological effects of chemicals. PhD thesis, Vrije Universiteit Amsterdam, p. 101.

Holdway, D.A., Brennan, S.E., Ahokas, J.T., 1995. Short review of selected fish biomarkers of xenobiotic exposure with an example using fish hepatic mixed-function oxidase. Austral. J. Ecol. 20, 34-44.

Johnsson, R.K., Wiederholm, T., Rosenberg, D.M., 1993. Freshwater biomonitoring using individual organisms and species assemblages of benthic macroinvertebrates. In: Rosenberg, D.M., Resh, V.H. (Eds.), Freshwater Biomonitoring and Benthic Macroinvertebrates. Chapman \& Hall, New York, pp. 40-159.

Ma, M., Wang, Z., Shang, W., Wang, C., Wang, W., 2000. Mutagenicity and acute toxicity of waters from different treatment processes in Beijing waterworks. J. Environ. Sci. Health (A) 35 (10), 88-96.

Podani, J., 2000. Introduction to Exploration of Multivariate Biological Data. Backhuys Publishers, Leiden, pp. 400.

Polman, H.J.G., De Zwart, D., 1993. The toxicity (pT-values) of organic concentrates of the river Meuse in the strech between Remilly (Fr) and Keizersveer (Nl). Proceedings of the International Conference on Rehabilitation of the River Rhine, Arnhem.
Rao, S.S., Metcalfe, C.D., Neheli, T.A. Schmidt, B., 1997. Assessing the toxicity of environmental contaminants with early life stages of Japanese Medaka (Oryzias latipes). Environment Canada National Water Research Institute, Burlington, Ontario, NWRI Contribution no. 97-02.

Rice, P.J., Drewes, C.D., Klubertanz, T.M., Bradbury, S.P., Coats, J.R., 1997. Acute toxicity and behavioral effects of chlorpyrifos, permethrin, phenol, strychnine, and 2,4 dinitrophenol to 30-day-old Japanese Medaka (Oryzias latipes). Environ. Toxicol. Chem. 16 (4), 696-704.

Schramm, M., Behrens, A., Braunbeck, T., Eckwert, H., Köhler, H.-R., Konradt, J., Müller, E., Pawert, M., Schwaiger, J., Segner, H., Triebskorn, R., 1999. Cellular histological and biochemical biomarkers. In: Gerhardt, A. (Ed.), Biomonitoring of Polluted Water-Reviews on Actual Topics. TTP, Zürich, Switzerland, pp. 33-65.

Schubauer-Berigan, M.K., Monson, P.D., West, C.W., Ankley, G.T., 1995. Influence of $\mathrm{pH}$ on the toxicity of ammonia to Chironomus tentans and Lumbriculus variegatus. Environ. Toxicol. Chem. 14 (4), 713-717.

Shi, Z., Mei, Z., 1995. Effects of nitrite on the survival of freshwater prawn Macrobrachium nipponensis. In: Munawar, M., et al. (Eds.), Aquatic Ecosystems of China: Environmental and Toxicological Assessment. SPB Academic Publishing, Amsterdam, Netherlands, pp. 83-89.

Shima, A., Shimada, A., 1994. The Japanese Medaka, Oryzias latipes, as a new model organism for studying environmental germ-cell mutagenesis. Environ. Health Persp. 102. Suppl. 12.

Tuvikene, A., Huuskonen, S., Roy, S., Lindström-Seppa, M., 1996. Biomonitoring of South Estonian waters by means of xenobiotic metabolism of rainbow trout (Oncorhynchus mykiss) liver. Comp. Biochem. Physiol. 114 C (2), 171177.

Water and Wastewater Monitoring and Analyzing Method (Ed.), 1989. Environmental Science Press, China.

Wolkers, J., Joergensen, E.H., Nijmeijer, S.M., Witkamp, R.F., 1996. Time-dependent induction of two distinct hepatic cytochrome P-4501A catalytic activities at low temperatures in Arctic charr (Salvelinus alpinus) after oral exposure to benzo(a)pyrene. Aquatic Toxicol. 35, 127-138.

World Bank (Ed.), 1998. China: Clear Water, Blue Skies. World Bank, Washington, USA.

\begin{abstract}
Almut Gerhardt (born 1959) holds a Ph.D. (1995) from Lund University (Sweden). She developed a new online biomonitor in her firm LimCo International. She edited the book "Biomonitoring of Polluted Water" (1999) and has published more than 30 peer-reviewed scientific papers in the fields of freshwater acidification, faunistics, aquatic ecotoxicology and biomonitoring.
\end{abstract}

Luc Janssens de Bisthoven (born 1964) finished his Ph.D. in 1995 at Catholic University of Leuven (Belgium). In his firm LimCo International he works on Chironomid ecotoxicology and deformities. He has 17 peer-reviewed scientific papers in the fields of fish ecology, conservation, chironomid deformities and aquatic ecotoxicology.

Zheng Mo (born 1974) graduated from the Northeast Normal University in 1998 and now studies for his masters degree in the Research Center for Eco-Environmental Sciences (RCEES), Chinese Academy of Sciences (CAS). 
Yang Min holds an M.S. and Ph.D. from Hiroshima University (Japan) and worked at Organo Co. Ltd. (Japan). From 1998 on he holds a professorship at the Research Center for Eco-Environmental Sciences (RCEES), Chinese Academy of Sciences (CAS).

Wang Chunxia (born 1963) finished her Ph.D. in Environmental Chemistry in 1994 and works at the Research Center for EcoEnvironmental Sciences (RCEES), Chinese Academy of Sciences (CAS). She has published more than 30 peer-reviewed scientific papers in the field environmental chemistry and ecotoxicology.

Wang Zijian (born 1953) finished his Ph.D. in 1990 and now works as a full professor at the Research Center for Eco-Environmental Sciences (RCEES), Chinese Academy of Sciences (CAS). He has published more than 140 peer-reviewed scientific papers in the field of environmental chemistry and ecotoxicology, amongst 42 in international journals. 